\title{
Barriers to Practice and the Impact on Health Care: A Nurse Practitioner Focus
}

\author{
MARY E. PETERSON, MS, APRN, AOCNP ${ }^{\circledR}$
}

From St. David's South Austin Medical Center, Austin, Texas

Author's disclosures of potential conflicts of intersst are found at the end of this article.

Correspondence to: Mary E. Peterson, MS, APRN, AOCNP®, HCA Physician Services Group, 4700 James Casey, Suite B-149, Austin, TX 78704. E-mail: Mary.Petersonz@hcahealthcare.com https://doi.org/10.6004/jadpro.2017.81.6 (c) 2017 Harborside Press ${ }^{\circledR}$
J Adv Pract Oncol 2017;8:74-81

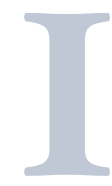
$\mathrm{n} 1965$, in answer to the growing demand for primary care, nursing pioneer Loretta Ford, along with Dr. Henry Silver, created the first certificate program that provided nurses with the skills to provide primary care to underserved populations. Since the inception of that first program, the field has grown to include adult/gerontology, women's health, neonatal, and other specialty roles, with minimum requirements for education at the master's/doctoral level.

The growth of nurse practitioners (NPs) across all 50 states is unsurprising given the current landscape of health care, yet barriers that limit practice need action at both the state and national levels. Access to care is a significant challenge for patients. This access is negatively impacted when qualified NPs are willing and able to deliver quality, cost-effective care, yet governmental bodies continue to ignore legislation that would update the laws and modernize health care.

IDENTIFYING RESTRICTIONS Individual states regulate NP practice. Currently, 22 states and the District of Columbia, or $44 \%$, have adopted full practice authority licensure and practice laws for NPs. Full practice author- ity is defined by the American Association of Nurse Practitioners (AANP) as follows: "State practice and licensure law provides for all nurse practitioners to evaluate patients, diagnose, order and interpret diagnostic tests, initiate and manage treatments-including prescribe medications-under the exclusive licensure authority of the state board of nursing." The remaining states are categorized as either "reduced practice" (17 states, or $34 \%)$ or "restricted practice" (12 states, or $24 \%$ ). The AANP further defines these categories as follows (AANP, 2016):

- Reduced Practice: The NP has the ability to engage in at least one element of the NP practice and is regulated through a collaborative agreement with an outside health discipline to provide patient care.

- Restricted Practice: The NP has the ability to engage in at least one element of NP practice and requires supervision, delegation, or team management by an outside health discipline to provide patient care.

In 2010, the Institute of Medicine (IOM), with the Robert Wood Johnson Foundation (RWJF), published a landmark report titled, "The Future 
of Nursing: Leading Change, Advancing Health." This paper outlined four key messages: (1) Nurses should practice to the full extent of their education; (2) nurses should achieve higher levels of education and training through an improved education system that promotes seamless academic progression; (3) nurses should be full partners, with physicians and other health-care professionals, in redesigning health care in the United States; and (4) effective work force planning and policy making require better data collection and an improved information infrastructure (IOM, 2010).

The report gives recommendations for implementing the key messages and recognizes "overly restrictive scope-of-practice regulation of NPs in some states as one of the most serious barriers to accessible care" (IOM, 2010). Soon after the release of this report, the RWJF, with the American Association of Retired Persons (AARP), launched the Future of Nursing: Campaign for Action (the Campaign), which has since worked at the national and state levels to shepherd the report's recommendations.

As a follow-up to the 2010 report, in 2015 RWJF released the report, "Assessing Progress on the Institute of Medicine Report: The Future of Nursing," which states that the Campaign had made significant progress in a short period of time, but points out that barriers still exist and more work needs to be done. The report adds that we need to continue to "address challenges in the areas of health care delivery and scope of practice, education, collaboration, leadership, diversity in the nursing profession, and work force data" (National Academies of Sciences, Engineering, and Medicine, 2015).

\section{SCOPE-OF-PRACTICE REGULATIONS}

Despite the original report in 2010, we still struggle against some of the same barriers. In some states, the battle to practice within the scope-of-practice regulations becomes further impeded by archaic hospital bylaws. Nurse practitioners with the same educational preparation and national certification may face a host of restrictions when relocating from one state to another, thus limiting their scope of practice (Safriet, 2011). Variations in the scope-ofpractice regulations across states have an indirect impact on patient care, as the degree of physician supervision may affect practice opportunities and payer polices for NPs (Yee et al., 2013).
Further research looks promising in regard to health-care costs. One such study in 2013 "was inconclusive for total health-care spending" (Martsolf et al., 2015). However, it did show that prices appear to go down slightly while utilization increases due to improvements in access to care. Spending in nine states that grant NPs full prescriptive authority does seem to increase slightly for some services, such as office visits, but acute coronary syndrome (ACS)-related emergency visits tend to drop.

Nurse practitioner independence might reorient spending toward higher-value services. If, as the studies suggest, full practice authority of NPs leads to more office-based primary care visits and checkups and fewer ACS emergency visits, then value per dollar spent should increase. There is not enough evidence to know the answer definitively. It does appear that restrictive laws could, in some states, force NPs to pay a significant share of practice revenues to their collaborating physicians.

Federal regulations place additional barriers on NP practice despite some small victories. The Balanced Budget Act of 1997 included the Primary Care Health Practitioner Incentive Act, perhaps the most important payment reform to affect NPs. Although the Primary Care Health Practitioner Incentive Act allowed for NPs to bill for services, one of the remaining challenges is the continued existence of the two-level fee structure. Nurse practitioners can receive $100 \%$ reimbursement for incident to services, but they cannot do so independently, thereby placing another barrier for the formation of independent practices and access to health care.

Many arguments against full practice cite safety as a concern. Evidence regarding the impact of NPs compared with physicians (MDs) on health-care quality, safety, and effectiveness has been systematically reviewed by Stanik-Hutt et al. (2013). Data from 37 of 27,993 articles published from 1990 to 2009 were summarized into 11 aggregated outcomes. According to the authors, "Outcomes for NPs compared to MDs (or teams without NPs) are comparable or better for all 11 outcomes reviewed".

\section{UPDATE ON RESTRICTIVE STATES}

Regardless of the overwhelming amount of data and evidence in support of full practice authority, many states continue to deny NPs the right to practice to the full extent of their license. According to 
the AANP (2016), the 12 restrictive states are California, Florida, Georgia, Massachusetts, Michigan, Missouri, North Carolina, Oklahoma, South Carolina, Tennessee, Texas, and Virginia.

Texas falls at the lower end of the spectrum regarding the freedoms it offers NPs. Despite legislative initiatives such as the Nurse Practitioner Full Practice Authority Bill (HB 1885) sponsored by Representatives Rodriguez and Burton at the 84th Legislative Session in 2015, the billed failed to make it to committee due to pressure from members of the State Medical Board. In many circles, especially health care in Texas, the term "good ole boy" may still ring true, reinforcing these barriers.

One misconception is that NPs want to broaden our scope of practice. We are simply trying to practice to the extent of our licensure. Specifically, in Texas, our scope is defined by the Board of Nursing as follows: "The advanced nurse practitioner acts independently and/or in collaboration with the health team in the observation, assessment, diagnosis, intervention, evaluation, rehabilitation, care and counsel, and health teachings of persons who are ill, injured or infirm, or experiencing changes in normal health processes; and in the promotion and maintenance of health or prevention of illness..." (21 Texas Administrative Code 221.13).

While many gains are promising, getting legislators to hear our bills can often be a daunting task. Many state NP organizations have hired lobbyists to help bring their efforts to the front line of legislators, although the medical boards in these states have significant influence and financial power to push their agendas through. It's time to change the focus from "us against them" to providing patients in the communities we serve with access to quality care.

"Instead of drawing divisive lines based on our training or credentials, we ought to find ways to identify and improve the poor performers in each group, without constraining the stars. Concluding that all doctors are great and all nurses just average is as misguided as judging someone's intellect by the college he or she attended" (Prasad, 2016). We need to adopt partnerships within the medical profession that support our initiatives and continue to present data that support full practice authority.

The National Council of State Boards of Nursing (NCSBN) tracks the practice roles and related bills for all advanced practice registered nurses.
The Table represents initiatives in restrictive authority states as previously outlined. The NCSBN attempts to maintain current active logs; however, all updates may not be represented in the Table. According to Maureen Cahill of the NCSBN, some gains were made in 2016 in both restrictive and nonrestrictive states-such as Virginia (clinical nurse specialist [CNS] role), West Virginia (autonomy after a transition period), Tennessee (title), Alaska (title and license), and Washington (CNS role)-but the fight is far from over.

It will take dedicated, determined leaders to help bring about change. As one of my colleagues, Erin Perez, NP, recently stated in an interview on full practice: "Do you want to own your practice, or are you just renting space?"

\section{Disclosure}

The author has no potential conflicts of interest to disclose.

\section{References}

American Association of Nurse Practitioners (AANP). (2016). State practice environment. Retrieved from https:// www.aanp.org/legislation-regulation/state-legislation/ state-practice-environment

Bankston, K., \& Glazer, G. (2013). Legislative: Interprofessional collaboration: What's taking so long? The Online Journal of Issues in Nursing, 19(1). http://www.nursingworld.org/MainMenuCategories/ANAMarketplace/ ANAPeriodicals/OJIN/Columns/Legislative/Interprofessional-Collaboration.html

Hain, D., \& Fleck, L. M. (2014). Barriers to NP practice that impact healthcare redesign. The Online Journal of Issues in Nursing, 19(2). http://www.nursingworld.org/MainMenuCategories/ANAMarketplace/ANAPeriodicals/ OJIN/TableofContents/Vol-19-2014/No2-May-2014/ Barriers-to-NP-Practice.html

Institute of Medicine (IOM). (2010). The future of nursing: Leading change, advancing health. Washington, DC: The National Academies Press.

Institute of Medicine (IOM). (2013). Interprofessional education for collaboration: Learning how to improve health from interprofessional models across the continuum of education to practice: Workshop summary. Washington, DC: The National Academies Press.

Institute of Medicine (IOM). (2015). Measuring the impact of interprofessional education on collaborative practice and patient outcomes. Washington, DC: The National Academies Press.

Interprofessional Education Collaborative Expert Panel. (2011). Core competencies for interprofessional collaborative practice: Report of an expert panel. Washington, DC: Interprofessional Education Collaborative.

Martsolf, G. R., Auerbach, D. I., \& Arifkhanova, A. (2015). The impact of full practice authority for nurse practitioners and other advanced practice registered nurses in Ohio. 


\section{Table. Legislation in States That Restrict Nurse Practitioners' Right to Practice}

\begin{tabular}{|c|c|c|c|c|}
\hline State & Legislation & Pending & Pass & Fail \\
\hline \multirow[t]{4}{*}{ California } & $\begin{array}{l}\text { CA S 323: Implementation of standardized procedures that } \\
\text { authorize an NP to perform certain acts }\end{array}$ & $\sqrt{ }$ & & \\
\hline & $\begin{array}{l}\text { CA A 637: Signature of NP or PA to create a valid physician } \\
\text { order for life-sustaining treatment }\end{array}$ & & $\sqrt{ }$ & \\
\hline & $\begin{array}{l}\text { CA S 960: Pertains to reproductive health, includes CNP, } \\
\text { CNM under medical program }\end{array}$ & $\sqrt{ }$ & & \\
\hline & $\begin{array}{l}\text { CA A 1306: Pertains to CNM full practice/prescribing } \\
\text { and scope }\end{array}$ & $\sqrt{ }$ & & \\
\hline \multirow[t]{13}{*}{ Florida } & $\begin{array}{l}\text { FL S 12: Mental health requires PMHNP to have } 2 \text { years' } \\
\text { supervision, then professionals shall practice to the full } \\
\text { extent of their license }\end{array}$ & & $\sqrt{ }$ & \\
\hline & $\begin{array}{l}\text { FL S 152: Expands prescribing under supervision, including } \\
\text { controlled substances }\end{array}$ & & & $\times$ \\
\hline & FL S 210: Limited controlled substance prescribing & & & $\times$ \\
\hline & $\begin{array}{l}\text { FL H 617: Pediatric cardiology does not have } \\
\text { advanced practice }\end{array}$ & & & $\times$ \\
\hline & $\begin{array}{l}\text { FL H 423: Expands controlled substance prescribing; } \\
\text { describes scope; language for CRNA, covers long-term care } \\
\text { and included PDMP }\end{array}$ & & $\sqrt{ }$ & \\
\hline & $\begin{array}{l}\text { FL H 977: PMH services bills, adds psychiatry to primary } \\
\text { care specialties list, restricts pain management to MD, } \\
\text { restricts prescribing of hormone-refractory depression, } \\
\text { narcolepsy, amphetamines; supervisory language for } \\
\text { protocol oversight and joint committee oversight }\end{array}$ & & $\sqrt{ }$ & \\
\hline & $\begin{array}{l}\text { FL S 946: Relates to authorized practices of APRNs and } \\
\text { PAs, authorizes physician to delegate a PA the authority } \\
\text { to order medications for patient during his/her care at } \\
\text { a licensed nursing facility; authorizes APRNs to order } \\
\text { medications for patients in specified facilities }\end{array}$ & & & $\times$ \\
\hline & FL H 979: Relates to PMH involuntary commitment & & & $\times$ \\
\hline & $\begin{array}{l}\text { FL H 1241: Authorizes controlled substance ordering in } \\
\text { specified facilities, contains supervision }\end{array}$ & & $\sqrt{ }$ & \\
\hline & $\begin{array}{l}\text { FL S 1250: Pertains to PMH expands authority for PMHNP } \\
\text { and PMHCNS to recommend admission/prescribing }\end{array}$ & & & $\times$ \\
\hline & FL S 1336: Pertains to behavioral health services & & & $\times$ \\
\hline & $\begin{array}{l}\text { FL H 1353/S1686: Creates telehealth taskforce, including } \\
\text { states' surgeon general and representatives of facilities and } \\
\text { health professionals }\end{array}$ & & & $\times$ \\
\hline & $\begin{array}{l}\text { FL H 7087/PCB6091: Pertains to telehealth; describes } \\
\text { providers and requires registering annually with the state, } \\
\text { on physicians practicing within scope, gives registration in } \\
\text { telehealth }\end{array}$ & & $\sqrt{ }$ & \\
\hline Georgia & \multicolumn{3}{|l|}{$\begin{array}{l}\text { GA } 3 \text { 114: Relates to APRN and the number of physicians } \\
\text { can delegate to }\end{array}$} & $\times$ \\
\hline \multicolumn{5}{|c|}{$\begin{array}{l}\text { Note. NP = nurse practitioner; PA = physician assistant; CNP = certified nurse practitioner; } C N M=\text { certified nurse } \\
\text { midwife; PMHNP = psychiatric mental health nurse practitioner; CRNA = certified registered nurse anesthetist; } \\
\text { PDMP = prescription drug monitoring program; PMH = psychiatric mental health; } M D=\text { doctor of medicine; APRN = } \\
\text { advanced practice registered nurse; PMHCNS = psychiatric and mental health clinical nurse specialist; CNS = clinical } \\
\text { nurse specialist; CPM = certified professional midwife; PMHCNP = psychiatric and mental health certified nurse } \\
\text { practitioner; RN = registered nurse; LPN = licensed practical nurse; AMA = American Medical Association; HMO = he } \\
\text { maintenance organization; PPO = preferred provider organization. }\end{array}$} \\
\hline
\end{tabular}


Table. Legislation in States That Restrict Nurse Practitioners' Right to Practice (cont.)

\begin{tabular}{|c|c|c|c|c|}
\hline \multirow{4}{*}{$\begin{array}{l}\text { State } \\
\text { Georgia (cont.) }\end{array}$} & Legislation & Pending & Pass & Fail \\
\hline & GA H 179: Relates to licensure for pain management clinics & & & $\times$ \\
\hline & $\begin{array}{l}\text { GA S 314: Changes definitions in statute to add title and } \\
\text { role recognition for all four APRN roles and adds population } \\
\text { foci; also provides for separate APRN license }\end{array}$ & & & $\times$ \\
\hline & $\begin{array}{l}\text { GA H 813: Expedited partner therapy; allows for it by APRNs } \\
\text { and pharmacists to dispense for control of venereal disease }\end{array}$ & & & $\times$ \\
\hline \multirow[t]{11}{*}{ Massachusetts } & $\begin{array}{l}\text { MA H 267: Pertains to telehealth: Aligns the state with federal } \\
\text { language physician driven, includes Medicaid; providers } \\
\text { have either written agreement or proxy credentialing to do } \\
\text { telehealth and insurers cannot specify site }\end{array}$ & $\sqrt{ }($ Stalled) & & \\
\hline & $\begin{array}{l}\text { MA SD 803: Pertains to full application of telemed } \\
\text { coverage; heard in committee }\end{array}$ & $\sqrt{ }$ & & \\
\hline & $\begin{array}{l}\text { MA S 1163: Carryover will give independent practice } \\
\text { authority and prescribing to CNPs and CRNAs who have } \\
\text { prescribed under supervision for a period of } 2 \text { years; it } \\
\text { also recognizes the collaborative/supervised practice of a } \\
\text { psychiatric mental health CNS }\end{array}$ & $\sqrt{ }$ & & \\
\hline & $\begin{array}{l}\text { MA S 1156: Seeks to establish a committee on midwifery } \\
\text { for CPMs to apply for licensure to the Board of Medicine; } \\
\text { eligibility would be a high school diploma and the } \\
\text { committee would set the midwifery education requirements }\end{array}$ & $\sqrt{ }$ & & \\
\hline & $\begin{array}{l}\text { MA S 1170: Pertains to team-based care; pending in } \\
\text { committee assigned study order }\end{array}$ & $\sqrt{ }$ & & \\
\hline & $\begin{array}{l}\text { MA S 1207: Removes restrictions on CNP and CNM carryover } \\
\text { from 2015; stalled in Senate health financing committee }\end{array}$ & $\sqrt{ }$ & & \\
\hline & $\begin{array}{l}\text { MA H 1889: Carryover independence for the CNP; } \\
\text { discharged to committee on House Ways and Means }\end{array}$ & $\sqrt{ }$ & & \\
\hline & $\begin{array}{l}\text { MA H 1996: Carryover regulates dispensing of controlled } \\
\text { substances; discharged to committee on House Ways } \\
\text { and Means }\end{array}$ & $\sqrt{ }$ & & \\
\hline & MA H 894: Relates to CNM; stalled in committee & $\sqrt{ }$ & & \\
\hline & MA H 3996: Nurse licensure compact & $\sqrt{ }$ & & \\
\hline & MA H 3969: Creates health disparities center & & $\sqrt{ }$ & \\
\hline \multirow[t]{4}{*}{ Michigan } & MI S 68: Establishes licensure requirements for APRNs & $\sqrt{ }$ & & \\
\hline & MI S 320: Pertains to CRNA & $\sqrt{ }$ & & \\
\hline & MI H 4207: Establishes licensure requirements for APRNs & $\sqrt{ }$ & & \\
\hline & $\begin{array}{l}\text { MI H 5400: Revised Yonker bill, has some language } \\
\text { that is not clear about Board oversight and rules; is } \\
\text { heavily amended }\end{array}$ & & $\sqrt{ }$ & \\
\hline \multirow[t]{5}{*}{ Missouri } & $\begin{array}{l}\text { MO S 621: Pertains to telehealth includes APRN; creates a } \\
\text { telehealth committee }\end{array}$ & $\sqrt{ }$ & & \\
\hline & MO S 752: Controlled substance schedule II limited supply & $\sqrt{ }$ & & \\
\hline & MO S 768: Relates to PDMP & $\sqrt{ }$ & & \\
\hline & $\begin{array}{l}\text { MO H 1465: Pertains to collaborative agreements, posting } \\
\text { notice, includes schedule II and III }\end{array}$ & $\sqrt{ }$ & & \\
\hline & MO H 1659: Pertains to reimbursement PMHCNP and PMHCNs & $\sqrt{ }$ & & \\
\hline \multicolumn{5}{|c|}{$\begin{array}{l}\text { Note. NP = nurse practitioner; PA = physician assistant; CNP = certified nurse practitioner; CNM = certified nurse } \\
\text { midwife; PMHNP = psychiatric mental health nurse practitioner; CRNA = certified registered nurse anesthetist; } \\
\text { PDMP = prescription drug monitoring program; PMH = psychiatric mental health; } M D=\text { doctor of medicine; APRN = } \\
\text { advanced practice registered nurse; PMHCNS = psychiatric and mental health clinical nurse specialist; CNS = clinical } \\
\text { nurse specialist; CPM = certified professional midwife; PMHCNP = psychiatric and mental health certified nurse } \\
\text { practitioner; RN = registered nurse; LPN = licensed practical nurse; AMA = American Medical Association; HMO = health } \\
\text { maintenance organization; PPO = preferred provider organization. }\end{array}$} \\
\hline
\end{tabular}


Table. Legislation in States That Restrict Nurse Practitioners' Right to Practice (cont.)

State

Missouri (cont.)

\section{Legislation}

MO H 1697: Pertains to collaborative; requires supervision of CRNA/maximum five collaborations limited supply

MO H 1866/S 826: Includes controlled substances II-V; only CRNA for anesthesia: Passed first committee with amendments; would allow schedule III, keeps collaborative

MO H 1906: Requires disclosure of anyone providing pregnancy care, including APRN

MO H 1923: Allows telehealth by APRN with a collaborative and if $M D$ is including telehealth in services

MO H 2043: Pertains to Nurse Licensure Compact

MO H 2275: Limits number of APRNs to physician

North Carolina NC [R] H 20: Updated (Text 2/4/2016); requires every physician, PA, and NP who provides well child care to ensure that each child receives diabetes screening at least once at birth, at 12 months of age, and at 24 months of age

NC S 240: Would add CRNA under Nurse Practice Act

NC H 372: Would make changes to existing Medicaid program, including implementing provider-led capitated plans. Governing bodies of these plans must comprise a majority of physicians, NPs, or psychologists

NC H 724: Adds one PA and one NP to Board of Medicine; previously, the member spot was allocated to one PA or one NP

NC H 774: Allows NPs and PAs to be present to administer lethal injection

NC [R] H 807: Updated (Text 2/4/2016); adds APRN to licenses Board of Nursing can grant, in addition to RN or LPN; defines practice of nursing as an APRN as specific acts in addition to RN scope of practice, including delegating to assistive personnel; conducting advanced assessments

NC S 695: Adds APRN to licenses Board of Nursing can grant; defines practice of nursing as an APRN as specific acts in addition to RN scope of practice, including delegating to assistive personnel; conducting advanced assessments; performing other acts that require education and training consistent with professional standards and commensurate with the APRN's education, certification, demonstrated competencies, and experience; recognizing limits of knowledge and experience; and planning for the management of situations beyond the APRN's expertise

Oklahoma
OK S 305: Pertains to telehealth

OK S 1434: Telehealth; allows state's rural health policy and research center to regulate and actualize telehealth; previous bill would allow PA through telehealth

OK S 1537: Creates state center for telemed pertaining to reimbursement, teleradiology

\section{Pending Pass}

$\sqrt{ }$

$\sqrt{ }($ Stalled $)$

$\sqrt{ }$

$\sqrt{ }($ Stalled)

v

$\sqrt{ }$

$\sqrt{ }$ (Stalled)

$\sqrt{ }$ 
Table. Legislation in States That Restrict Nurse Practitioners' Right to Practice (cont.)

\begin{tabular}{|c|c|c|c|c|}
\hline State & Legislation & Pending & Pass & Fail \\
\hline \multirow[t]{2}{*}{$\begin{array}{l}\text { Oklahoma } \\
\text { (cont.) }\end{array}$} & $\begin{array}{l}\text { OK H 2841: Removes the requirement for a collaborative } \\
\text { practice agreement and permits the Board of Nursing to } \\
\text { grant full prescriptive authority to qualifying APRNs, also } \\
\text { working on Board consolidation }\end{array}$ & $\sqrt{ }($ Stalled $)$ & & \\
\hline & OK H 2482: Nurse licensure compact, enrolled & & $\sqrt{ }$ & \\
\hline \multirow[t]{2}{*}{ South Carolina } & $\begin{array}{l}\text { SC S 1035: Pertains to telehealth-delegated medical acts to } \\
\text { APRN }\end{array}$ & & $\sqrt{ }$ & \\
\hline & SC H 3078: Amendments; retains supervision, protocols & $\sqrt{ }($ Stalled) & & \\
\hline \multirow[t]{3}{*}{ Tennessee } & $\begin{array}{l}\text { TN H 861: AMA bill requires APRNs to practice on } \\
\text { physician-led teams }\end{array}$ & $\sqrt{ }($ Stalled) & & \\
\hline & TN S 660: Medical cannabis & $\sqrt{ }($ Stalled) & & \\
\hline & TN S 725: Telehealth insurance coverage & $\sqrt{ }($ Stalled) & & \\
\hline \multirow[t]{9}{*}{ Texas } & $\begin{array}{l}\text { HB 1885/SB 751: Authorized APRNs to evaluate and } \\
\text { diagnose patients; order and interpret diagnostic tests; and } \\
\text { initiate and manage treatments (including the prescribing } \\
\text { of medications) under the exclusive licensure authority of } \\
\text { the Texas Board of Nursing; APRNs would no longer need } \\
\text { to secure a physician to delegate this authority }\end{array}$ & & & $\times$ \\
\hline & $\begin{array}{l}\text { HB 3398/SB 1980: Allow Medicaid managed-care } \\
\text { plans, HMOs, and PPOs to recognize APRNs as primary } \\
\text { care providers and include them in the list of provider } \\
\text { directories, regardless of whether or not their delegating } \\
\text { physician is in an insurer's network }\end{array}$ & & & $\times$ \\
\hline & $\begin{array}{l}\text { HB 1473: Would have allowed APRNs to sign paperwork } \\
\text { certifying the care or condition of their patients, including } \\
\text { certification of disability for patient to receive disabled } \\
\text { parking permits or placards, signing physicals for student } \\
\text { athletes, and signing workers compensation for employees } \\
\text { on the job }\end{array}$ & & & $\times$ \\
\hline & $\begin{array}{l}\text { HB 3912: Would have allowed APRNs to sign the medical } \\
\text { certification portion of a death certificate for patients under } \\
\text { their care }\end{array}$ & & & $\times$ \\
\hline & $\begin{array}{l}\text { HB 2602: This bill would have allowed physicians to } \\
\text { delegate ordering and prescribing of Schedule II Controlled } \\
\text { Substances to APRNs specializing in psychiatric/mental } \\
\text { health and palliative care }\end{array}$ & & & $\times$ \\
\hline & $\begin{array}{l}\text { SB 466: Would have granted APRNs the authority to } \\
\text { complete and sign the required statement for patients } \\
\text { seeking exemption from jury service for a physical or } \\
\text { mental impairment }\end{array}$ & & & $\times$ \\
\hline & $\begin{array}{l}\text { SB 195: Transfers regulation of the state's prescription drug } \\
\text { monitoring program from the Department of Public Safety } \\
\text { (DPS) to the Texas State Board of Pharmacy and phases out } \\
\text { the Controlled Substance Registration process with DPS }\end{array}$ & & $\sqrt{ }$ & \\
\hline & $\begin{array}{l}\text { SB 239: Establishes a loan repayment assistance for APRN } \\
\text { mental health providers in rural or underserved areas }\end{array}$ & & $\sqrt{ }$ & \\
\hline & $\begin{array}{l}\text { SB 1753: Effective } 2020 \text {, this bill will require a health-care } \\
\text { provider in a hospital to wear a photo ID badge with name, } \\
\text { department, and license type (e.g., nurse practitioner, nurse } \\
\text { midwife, nurse anesthetist, or clinical nurse specialist) }\end{array}$ & & $\sqrt{ }$ & \\
\hline \multicolumn{5}{|c|}{$\begin{array}{l}\text { Note. NP = nurse practitioner; PA = physician assistant; CNP = certified nurse practitioner; } C N M=\text { certified nurse } \\
\text { midwife; PMHNP = psychiatric mental health nurse practitioner; CRNA = certified registered nurse anesthetist; } \\
\text { PDMP = prescription drug monitoring program; PMH = psychiatric mental health; } M D=\text { doctor of medicine; APRN = } \\
\text { advanced practice registered nurse; PMHCNS = psychiatric and mental health clinical nurse specialist; CNS = clinical } \\
\text { nurse specialist; CPM = certified professional midwife; PMHCNP = psychiatric and mental health certified nurse } \\
\text { practitioner; RN = registered nurse; LPN = licensed practical nurse; AMA = American Medical Association; HMO = health } \\
\text { maintenance organization; PPO = preferred provider organization. }\end{array}$} \\
\hline
\end{tabular}




\begin{tabular}{|c|c|c|c|c|}
\hline State & Legislation & Pending & Pass & Fail \\
\hline \multirow[t]{2}{*}{ Texas (cont.) } & $\begin{array}{l}\text { SB 1235: Increases criminal penalties for "pill mill activities" } \\
\text { and clarifies the persons considered to be operators of a } \\
\text { pain management clinic to include not just clinic or practice } \\
\text { owners, but also medical directors and physicians engaged } \\
\text { in supervision or delegation activities related to the clinic }\end{array}$ & & $\sqrt{ }$ & \\
\hline & $\begin{array}{l}\text { HB 495: Ensures that the tobacco lawsuit settlement funds } \\
\text { continue to be dedicated to the Texas Higher Education } \\
\text { Coordinating Board for the Nursing Education Innovative } \\
\text { Grant Program }\end{array}$ & & $\sqrt{ }$ & \\
\hline \multirow[t]{8}{*}{ Virginia } & VA S 19: Pertains to telemedicine & & & $\times$ \\
\hline & $\begin{array}{l}\text { VA S 212: Pertains to composition of Board of Health and } \\
\text { Board of Nursing: two NPs required }\end{array}$ & & $\sqrt{ }$ & \\
\hline & $\begin{array}{l}\text { VA S 264: Governor's bill allows for required practice on } \\
\text { a health-care team to include telemedicine; defines some } \\
\text { circumstances of practice outside of a team }\end{array}$ & & $\sqrt{ }$ & \\
\hline & $\begin{array}{l}\text { VA H 330: CNS remains under Board of Nursing, advanced } \\
\text { practice }\end{array}$ & & $\sqrt{ }$ & \\
\hline & $\begin{array}{l}\text { VA S 369: Allows for pilot program for physicians to serve } \\
\text { as team leads for NPs in practice in medically underserved } \\
\text { areas; still requires practice only on a physician-led team; } \\
\text { allows telehealth }\end{array}$ & $\sqrt{ }$ & & \\
\hline & $\begin{array}{l}\text { VA S 463: CNM and CNP: permits CNM to prescribe } \\
\text { controlled substance II-V agents within a collaborative } \\
\text { arrangement }\end{array}$ & & $\sqrt{ }$ & \\
\hline & $\begin{array}{l}\text { VA H 581: Gives NPs } 60 \text { days to continue to treat patients if } \\
\text { they lose their collaborator, as long as they only prescribe } \\
\text { drugs that were previously authorized under their } \\
\text { agreement, and can extend by an additional } 60 \text { days if they } \\
\text { demonstrate continued effort to secure a collaborator }\end{array}$ & & $\sqrt{ }$ & \\
\hline & $\begin{array}{l}\text { VA S 620: Removed team requirement for NPs; carryover to } \\
\text { next session }\end{array}$ & $\sqrt{ }$ & & \\
\hline \multicolumn{5}{|c|}{$\begin{array}{l}\text { Note. NP = nurse practitioner; PA = physician assistant; CNP = certified nurse practitioner; } C N M=\text { certified nurse } \\
\text { midwife; PMHNP = psychiatric mental health nurse practitioner; CRNA = certified registered nurse anesthetist; } \\
\text { PDMP = prescription drug monitoring program; PMH = psychiatric mental health; } M D=\text { doctor of medicine; } A P R N= \\
\text { advanced practice registered nurse; PMHCNS = psychiatric and mental health clinical nurse specialist; CNS = clinical } \\
\text { nurse specialist; CPM = certified professional midwife; PMHCNP = psychiatric and mental health certified nurse } \\
\text { practitioner; RN = registered nurse; LPN = licensed practical nurse; AMA = American Medical Association; HMO = health } \\
\text { maintenance organization; PPO = preferred provider organization. }\end{array}$} \\
\hline
\end{tabular}

Retrieved from http://www.rand.org/pubs/research_reports/RR848.html

National Academies of Sciences, Engineering, and Medicine. (2015). Assessing progress on the Institute of Medicine Report: The future of nursing. Washington, DC: The National Academies Press.

Prasad, V. (2016). Let nurse practitioners work independently. Retrieved from https://www.statnews.com/2016/05/24/ nurse-practitioners-doctors/

Safriet, B. J. (2011). Federal options for maximizing value of advanced practice nurses in providing quality, cost-effective health care. The future of nursing: Leading change, advancing health. Washington, DC: The National Academies Press.

Stanik-Hutt, J., Newhouse, R. P., White, K. M., Johantgen, M., Bass, E. B., Zangaro, G.,...Weiner, J. P. (2013). The quality and effectiveness of care provided by nurse practitioners. Journal for Nurse Practitioners, 9(8), 492-500.e.13. http://dx.doi.org/10.1016/j.nurpra.2013.07.004

Sullivan, M., Kiovsky, R. D., Mason, D. J., Hill, C. D., \& Dukes, C. (2015). Interprofessional collaboration and education: Working together to ensure excellence in health care. American Journal of Nursing, 115(3), 47-53. https://doi. org/10.1097/01.NAJ.0000461822.40440.58

US Department of Health and Human Services (HHS), Health Resources and Services Administration, National Center for Health Workforce Analysis. (2014). The future of the nursing workforce: National- and state-level projections, 2012-2025. Rockville, Maryland: HHS.

Yee, T., Boukus, E., Cross, D., \& Samuel, D. (2013). Primary care workforce shortages: Nurse practitioner scopeof-practice laws and payment policies. Retrieved from http://nihcr.org/wp-content/uploads/2015/03/NIHCR Research_Brief_No._13.pdf 